\title{
Potential use of aquatic plants in constructed wetlands for simultaneous removal of Phosphate and COD from laundry wastewater
}

\author{
Marcorio A Tefa ${ }^{1}$, Donny Harisuseno ${ }^{1}$, Riyanto Haribowo ${ }^{1}$ \\ ${ }^{1}$ Water Resources Engineering Department, Universitas Brawijaya, Malang, 65145, \\ Indonesia \\ riyanto_haribowo@ub.ac.id \\ Received 27-07-2018; revised 01-09-2018; accepted 26-09-2018
}

\begin{abstract}
One component of household wastewater that has a bad impact on the environment is waste that comes from washing which uses detergent, due to a fairly high phosphate and chemical oxygen demand (COD) concentration. The purpose of this study was to determine the potential of using aquatic plants to reduce phosphate and COD levels from laundry waste. This research was carried out using constructed wetlands model of laboratory scale using the combination of flow types of subsurface flow systems (SFS) and the type of vertical flow system (VFS) with a waste residence time of 5 days and 10 days. Based on the results, for model I, the average percentage of COD levels reduction is $67.62 \%$ and phosphate is $13.89 \%$, while in model II, the average percentage of COD reduction is $59.93 \%$ and phosphate is $14.36 \%$, after 10 days of waste residence time. Aquatic plants used in the modeling of constructed wetland can grow and reproduce well, this can be indicated by the growth of new shoots and flowers of these plants.
\end{abstract}

Keywords: constructed wetland, COD, detergent waste, phosphate

\section{Introduction}

As a cleaning material, detergent is a product of technological advances that utilize chemicals containing phosfat, silicate, coloring agents and fragrance ingredients [1]. Around the 1960s, early generation detergents emerged using Alkyl Benzene Sulfonate (ABS) surface-activating chemicals (surfactants) which were able to produce foam [2]. In many countries in the world the use of ABS has been banned because of its nature which is difficult to describe by microorganisms on the surface of the land, but in Indonesia the regulations regarding the use of ABS has not been clearly implemented. Some reasons for the use of ABS in detergent products among others the cheap price, the stability in the form of cream/pasta and the abundant foam [3]. Detergents containing ABS is a relatively harsh detergents, because it is included in the non-biodegradable or difficult to decomposed by microorganisms. In addition to surfactants, important ingredients in detergent content is builders. Builders function to increase the efficiency of washing from surfactants by deactivating minerals that cause water hardness. The most used builders in detergents is Phosphate $[4,6,7]$. 
Currently, a simpler alternative waste treatment has been developed, namely an artificial wetland system by utilizing sunlight and plants that function to filter out pollutants with the help of microorganisms that grow in roots without adding chemicals and the process goes naturally [5]. This method is easy to implement and safe to use with a relatively small negative impact and does not require large costs. Wetlands proved to be able to reduce levels of Biological Oxygen Demand (BOD), COD, Total Suspended Solids (TSS), Nitrogen (N) and Phosphate (P), and also coli bacteria significantly $[8,9]$.

There are several ways that can be done to treat wastewater. Natural biological processing is one of the alternative processing that does not require high costs, namely by utilizing aquatic plants, wherein the content of organic material that is available will be used as nutrients in the metabolic process by aquatic plants $[10,11,16]$.

Aquatic plants have the ability to absorb nutrients which are pollutants (organic and inorganic) from wastewater, for their metabolic purposes. The use of aquatic plants to treat wastewater using a constructed wetland system utilizes the symbiosis between soil microorganisms and the roots of aquatic plants that will release oxygen. Microbes contained in wastewater will use oxygen to decompose organic matter, so that in this process mutual symbiosis occurs in two living creatures in this wastewater treatment. In this study, the aquatic plants used were sagittaria montevidensis (water lilies) and canna sp (kana) [12,13].

From this study, it is expected to found out how the differences between the effectiveness of constructed wetland using Sagittaria montevidensis (water lilies) and constructed wetlands using Canna Sp (kana) plants, to reduce COD and phosphate levels in detergent waste, and how physical changes occur in aquatic plants.

\section{Material and Methods}

\subsection{Wetland Modeling Design}

The research was conducted in Laboratory of Water and Land, Department of Water Resources Engineering, Faculty of Engineering, Universitas Brawijaya. Waste water used in modeling is detergent waste water (domestic waste), which is tested first in the laboratory before being modeled on constructed wetland.

Constructed wetlands are modeled with plastic container tanks with dimensions: length $=60 \mathrm{~cm}$; width $=35 \mathrm{~cm}$; and height $=55 \mathrm{~cm}$ (Figure 1). The selection of container tanks with these dimensions is based on constructed wetland design criteria, namely:

a) Detention time design parameters using type flow of sub surface flow between 5-10 days.

b) The water depth parameters for construction range from 0.1 to $1.0 \mathrm{~m}$.

c) The type of plant used has the length of root zone between $15-61 \mathrm{~cm}$ and this type of plant can be used in wetland planning with free surface and sub surface flow types.

The test plants used were Sagittaria montevidensis (water lilies) and Canna Sp (kana). Conditioning is carried out for 2 weeks, during which time the plant is considered able to adapt to its new media. Acclimatization is carried out by gradually being replaced with existing wastewater for 2 weeks. The replacement of ordinary water with waste water is by adding waste water and reducing the volume of the water until the waste water reaches $100 \%$. After the specified time, a healthy test plant is planted into the test reactor. The taking of the test plant from the acclimatization site must be with the soil so as not to damage the root of the plant, then removed from the roots of the plant by immersing it in water while removing the soil attached to the roots. If the roots are clean, plants can be planted on wetland media with a depth of $10 \mathrm{~cm}$ from the base.

This study uses 2 models of constructed wetland:

1. Model I

The pool is filled with the vegetation of the Sagittaria montevidensis plant combined with filter media, namely soil, sand, gravel, with the planned composition and volume. Then flowed with detergent wastewater from washing result manually. The processing zone is filled with soil 
substrate $=0.0263 \mathrm{~m}^{3} ;$ sand $=0.0175 \mathrm{~m}^{3}$; gravel $=0.0086 \mathrm{~m}^{3}$, and Sagittaria montevidensis plant. Filter media in the form of soil, sand and gravel are arranged in a plastic container, which is bounded by a wire screen, according to the size and volume planned.

2. Model II

The arrangement, size and volume of the filter media are the same as in the design of constructed wetland model I. The basic difference in this model is the type of plant, which is using Canna sp (kana), with the aim to be compared with model I.

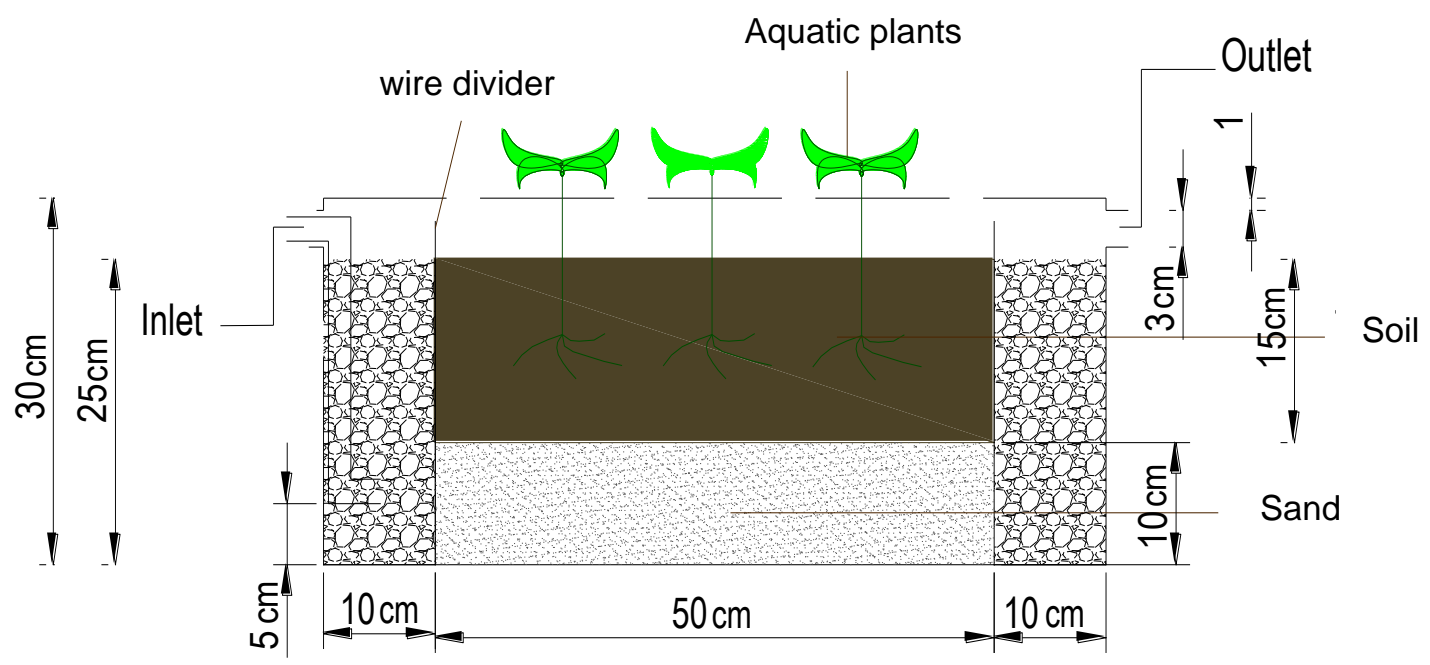

Figure 1. Modeling design of constructed wetland (side view).

This type of flow applied to the constructed wetland modeling is the Vertical Flow System (VFS) flow type. Modeling is divided into 3 zones, namely inlet zone, processing zone (wetland), and outlet. The inlet and outlet zones are filled with small to medium sized gravels, with the aim of avoiding the blocking so that the flow can run smoothly. In the processing zone, it is filled with aquatic plants and substrate/filter media in the form of sand and soil.

Waste water is flowed into the system, with the smallest possible discharge, so that the detention/ residence time of the waste in the constructed wetland is longer. This process is carried out for 10 days for each model. Determination of 10 days assumes that with this time it is considered sufficient to observe the efficiency of the reduction of waste pollutants.

\subsection{Parameter Testing}

Chemical parameter testing is carried out per 5 days, whereas analysis of the changes that occur in plants is carried out after 10 days of waste residence/ detention time. After that, 3 (three) repetitions were carried out on each model, by replacing the plants and substrate/filter media. This is intended to determine the validity of the results obtained in previous studies. The sequence of parameter testing is: measurement of COD, measurement of Phosphate [14] and analysis of plant changes.

\subsection{Data analysis}

The data obtained is used as a basis to conduct an analysis which refers to the literature study. Data presentation in the form of tabulations and graphs, so that from the changes in the numbers of each parameter can describe the efficiency of processing system with the constructed wetland.

$$
\text { Percentage of reduction }(\%)=\frac{\left(\mathrm{C}_{0}-C_{1}\right)}{C_{0}} \times 100 \%
$$

Where: $\quad \mathrm{C}_{0}=$ initial parameter concentration

$$
\mathrm{C}_{1}=\text { parameter concentration on the reactor effluent }
$$


The reduction percentage of each reactor is presented in the form of graphs and tables so that it can be seen the magnitude of the decrease in each parameter [15].

\section{Result and Discussion}

\subsection{COD Parameters Reduction}

Based on testing in the laboratory, obtained the initial sample results from the parameters of COD and Phosphate in detergent wastewater, namely $752 \mathrm{mg} / 1$ and $42.56 \mathrm{mg} / 1$. The amount of the initial sample number of the COD and Phosphate parameters in detergent wastewater is included in the "strong" category for the characteristics of Indonesian domestic wastewater. Thus, it is necessary to treat the wastewater, to reduce the levels of COD and Phosphate contained therein.

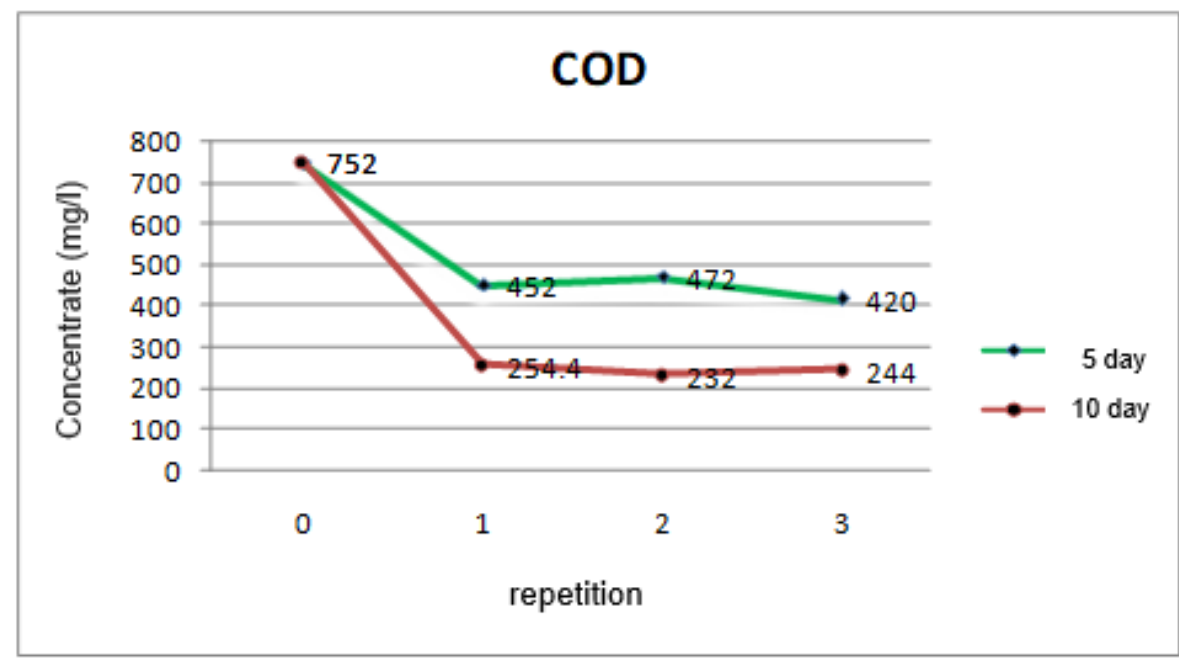

Figure 2. COD parameter changes in model I

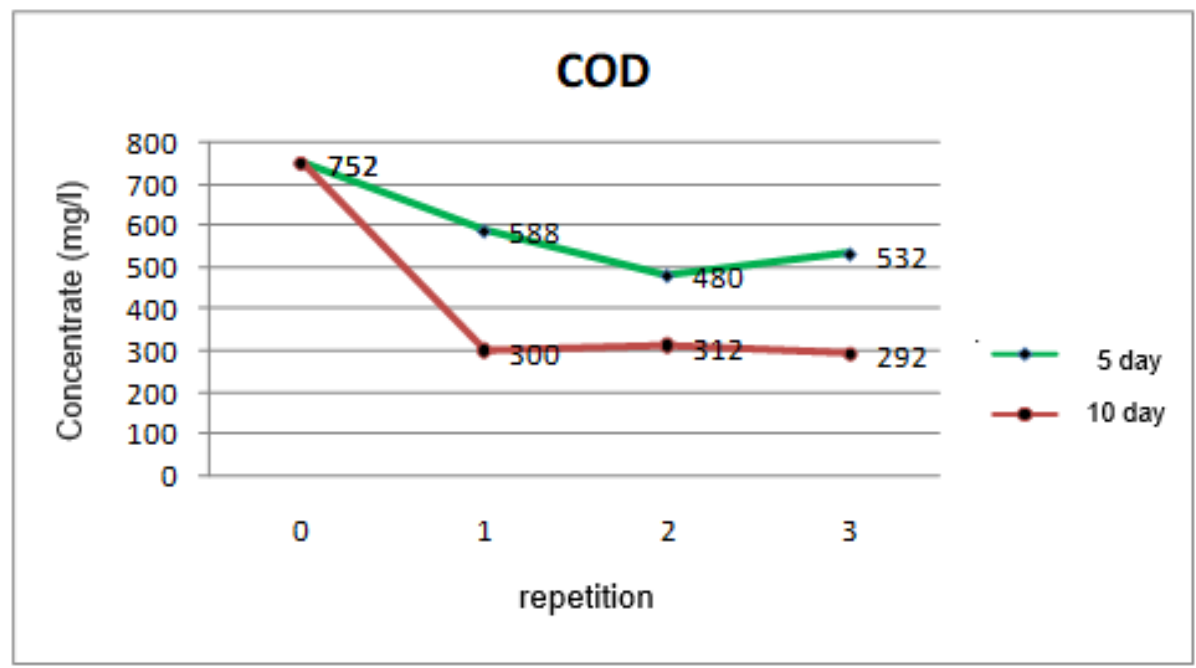

Figure 3. COD parameter changes in model II

Changes that occur are COD levels have decreased after going through the processing/ treatment process in constructed wetland modeling on model I, with a residence time of 5 days and 10 days, from 3 repetitions (Figure 2). For the 5-day residence time, the largest decrease in COD levels in the third experiment, namely equal to $332 \mathrm{mg} / \mathrm{l}$ from the initial sample of $752 \mathrm{mg} / \mathrm{l}$ or experiencing a 
decrease in percentage of $44.15 \%$. For the 10-day residence time, the biggest decrease in COD levels was in the second experiment, which was $520 \mathrm{mg} / 1$ from the initial sample of $752 \mathrm{mg} / 1$ or experienced a decrease in percentage of $69.15 \%$.

COD levels have decreased, both for 5 days and 10 days, from each experiment (Figure 3). For the 5 -day residence time, the biggest decrease in COD levels was in the second experiment, namely equal to $272 \mathrm{mg} / 1$ from the initial sample of $752 \mathrm{mg} / 1$ or experienced a decrease in percentage of $36.17 \%$. For the 10-day residence time, the biggest decrease in COD levels was in the third experiment, namely as much as $460 \mathrm{mg} / 1$ from the initial sample of $752 \mathrm{mg} / 1$ or experienced a decrease in percentage of $61.17 \%$. From both treatments it can be concluded that the longer the contact time of wastewater with filtration media and plants used in the modeling of constructed wetland, the more optimal the absorption process of COD levels in the wastewater.

\subsection{Phosphate Parameters Reduction}

Phosphate levels decreased, both for 5 days and 10 days, from each experiment (Figure 4). For a 5day residence time, there was the same decrease in phosphate levels from the three trials, namely equal to $2.95 \mathrm{mg} / \mathrm{l}$ from the initial sample of $42.56 \mathrm{mg} / \mathrm{l}$ or experienced a decrease in percentage of $6.93 \%$. For the 10-day residence time, the largest reduction in phosphate levels was at the first trial, which was $7.09 \mathrm{mg} / 1$ from the initial sample of $42.56 \mathrm{mg} / \mathrm{l}$ or experiencing a decrease in percentage of $16.66 \%$.

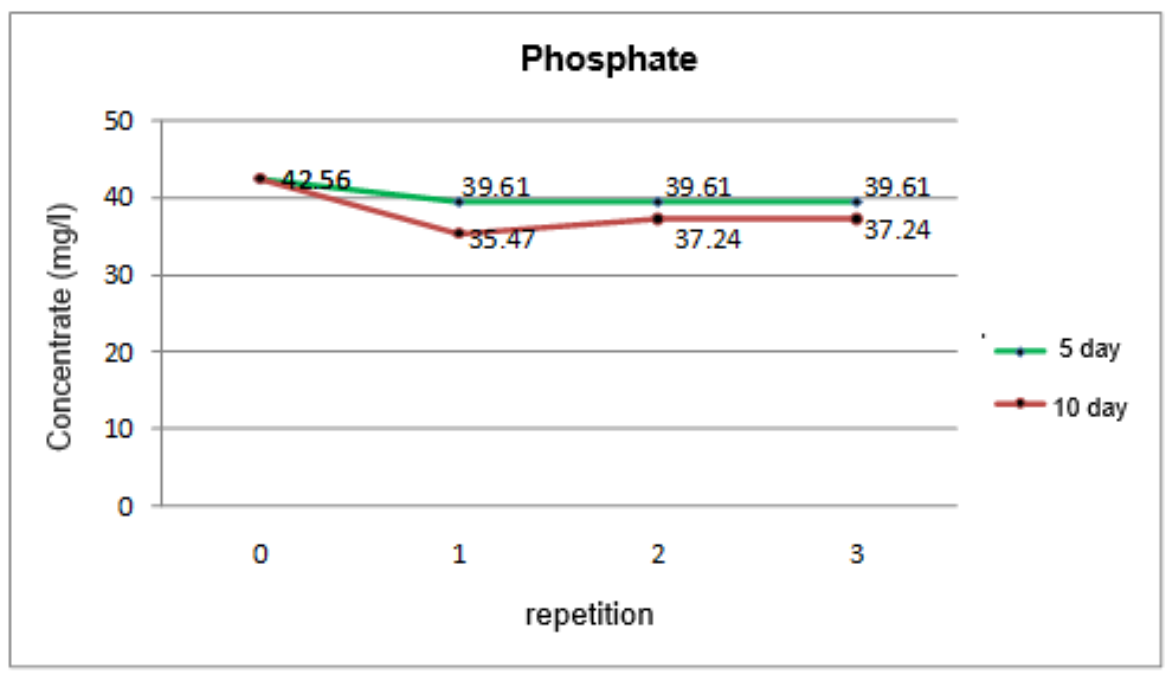

Figure 4. Phosphate parameters change in model I

Figure 5 describes the change in phosphate parameters in model II, from the initial sample of 42.56 $\mathrm{mg} / \mathrm{l}$. Phosphate levels have decreased after going through the processing/treatment process in constructed wetland modeling in model II, with a residence time of 5 days and 10 days, from 3 times the repetition process. For a 5-day residence time, the greatest decrease in phosphate levels in the first and second trials, ie equal to $4,14 \mathrm{mg} / 1$ from the initial sample of $42.56 \mathrm{mg} / \mathrm{l}$ or experiencing a decrease in percentage of $9.73 \%$. For the 10-day residence time, the largest decrease in Phosphate levels was in the second experiment, namely equal to $6.5 \mathrm{mg} / \mathrm{l}$ from the initial sample of $42.56 \mathrm{mg} / \mathrm{l}$ or experienced a decrease in percentage of $15.27 \%$. Similar to COD concentration, the longer the contact time of wastewater with filtration media and plants used in modeling constructed wetland, the more optimal the absorption process of Phosphate levels in the wastewater. 


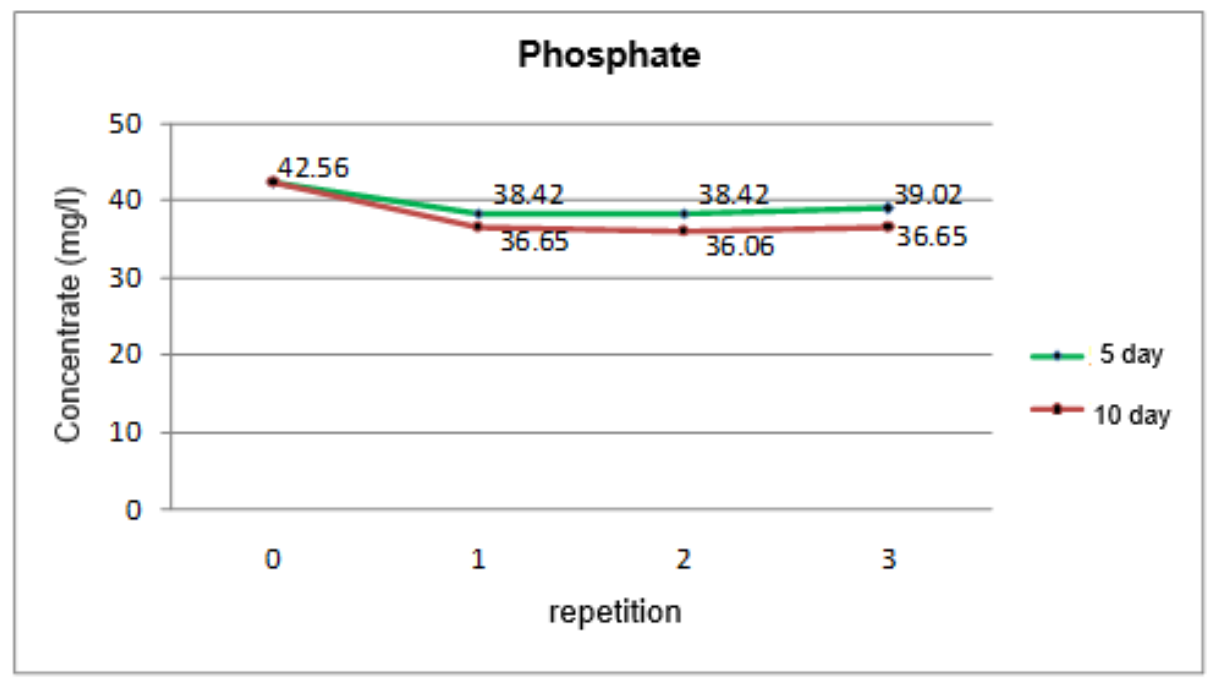

Figure 5. Phosphate parameters change in model II

From the results of the research obtained, it can be concluded that both constructed wetland modeling succeeded in reducing the levels of COD and Phosphate in detergent wastewater, both for the waste residence/detention time of 5 days and 10 days for three repetitions. Although, it can be seen that there are differences in the results of the parameters of each trial/experiment ( 3 repetitions). Differences in numbers and percentage of decline that occur from each experiment, due to the initial sample parameters COD and Phosphate from detergent waste water measured and used as a comparison only in the initial drainage. This causes, it is very possible that there is a difference in the levels of COD and Phosphate from detergent wastewater used for subsequent drainage. But by looking at the difference in numbers and the percentage of decline that is not too large from each experiment, the results of this study can be said to be valid after going through the process of three repetitions.

\subsection{Comparison of The Decreases in COD and Phosphate Levels}

Constructed wetland modeling in this study consists of two models. Each model uses the same substrate/filter media (gravel, sand and soil), with sagittaria montevidensis (model I) aquatic plants and canna sp (model II) aquatic plants. Therefore, with the differences in the use of aquatic plants in this study, it is intended as a comparison to determine the extent of the difference in the decrease in COD and Phosphate levels in detergent wastewater from both constructed wetland modeling.

\subsubsection{COD level}

From the results of laboratory tests, it can be seen that the difference in COD levels occurred in the modeling of constructed wetland model I and model II from each experiment (3 repetitions). From the analysis results (Figure 6) it can be seen that, the decrease in COD levels for the 5-day residence time in model I was greater than the model II. The biggest difference in the decline occurred in the third experiment, namely the difference in the percentage of reduction equal to $14.89 \%$. While the difference in the average percentage of decrease in each experiment ( 3 repetitions) of the two constructed wetland modeling models is $9.13 \%$.

For the 10-day waste detention time, the same as for the 5-day waste residence time, the decrease in COD levels in model I was also greater than in model II. The biggest difference in the decline of the two models occurred in the second experiment, with a difference in the reduction percentage equal to $10.64 \%$. While the difference in the average percentage of reduction in each experiment (3 times repetition) of the two constructed wetland modeling models is $7.69 \%$ (Figure 7). Thus, it can be concluded that modeling of constructed wetland model I using sagittaria montevidensis aquatic plants is better in reducing COD levels in detergent wastewater, when compared with the modeling of 
constructed wetland model II that uses canna sp aquatic plants, although the comparison is not too large.

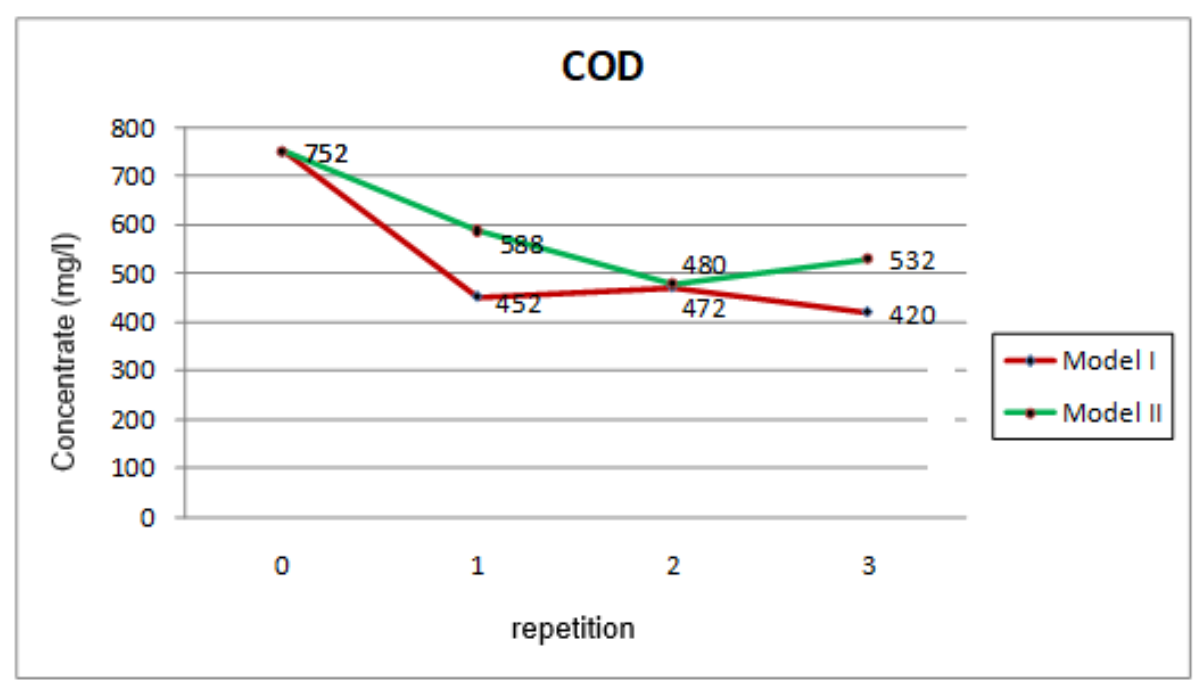

Figure 6. Comparison of laboratory test results of COD parameters for 5 days

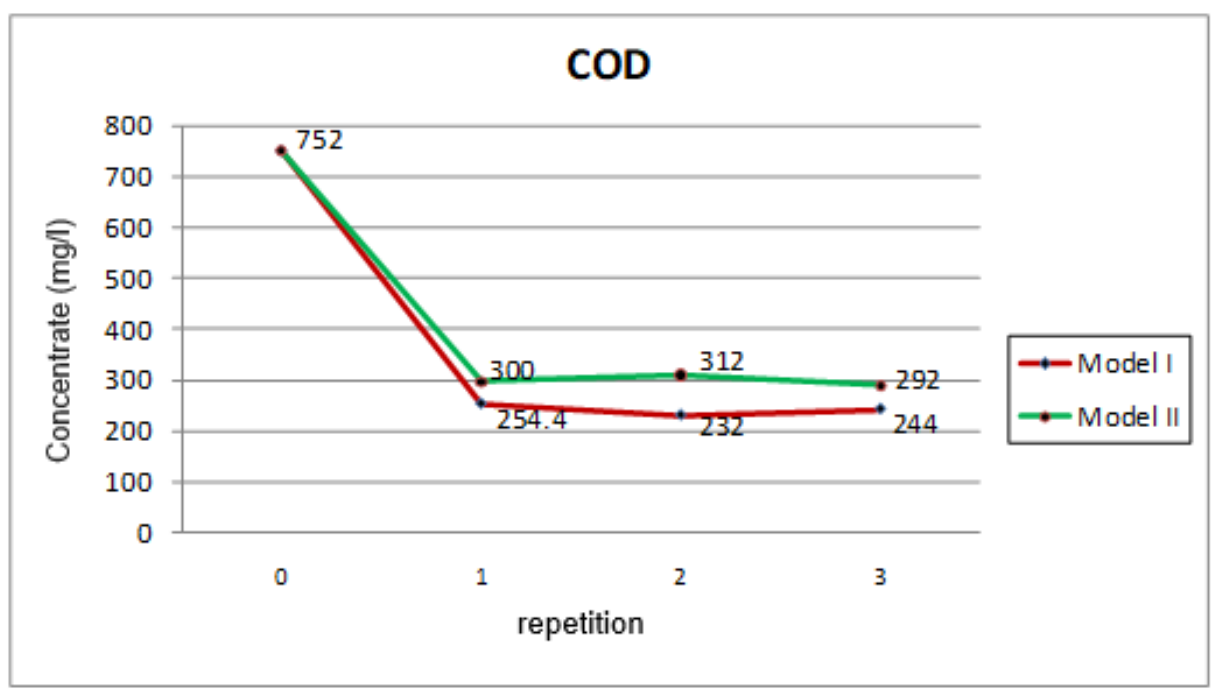

Figure 7. Comparison of laboratory test results of COD parameters for 10 days

\subsubsection{Phosphate levels}

From the results of laboratory tests, it can be seen that the difference in Phosphate levels occurs in the modeling of constructed wetland model I and model II from each experiment (3 repetitions). The decrease in Phosphate levels for the 5-day residence time in model II is greater than model I. The biggest difference in the decline occurred in the first and second experiments, namely the difference in the percentage reduction equal to $2.8 \%$. Whereas in the third experiment, the difference in the percentage of decline was smaller, namely $1.39 \%$. Thus, the difference in the average percentage of decrease in each experiment (3 times repetition) from the two models of constructed wetland modeling equal to $2.33 \%$ (Figure 8 ).

For a 10-day residence time, there is a comparison of the Phosphate parameter reduction which varies from both constructed wetland modeling on the three conducted experiments. In the first experiment, the decline that occurred in model I was greater, namely by the difference in the reduction percentage $2.77 \%$. But in the second and third trials, the decline that occurred in model II was greater, namely by the difference in the reduction percentage $2.77 \%$ in the second experiment and $1.39 \%$ in the 
third experiment. The average percentage of reduction from each experiment ( 3 repetitions) in model II was also greater, namely by the difference in the reduction percentage $0.47 \%$ (Figure 9).

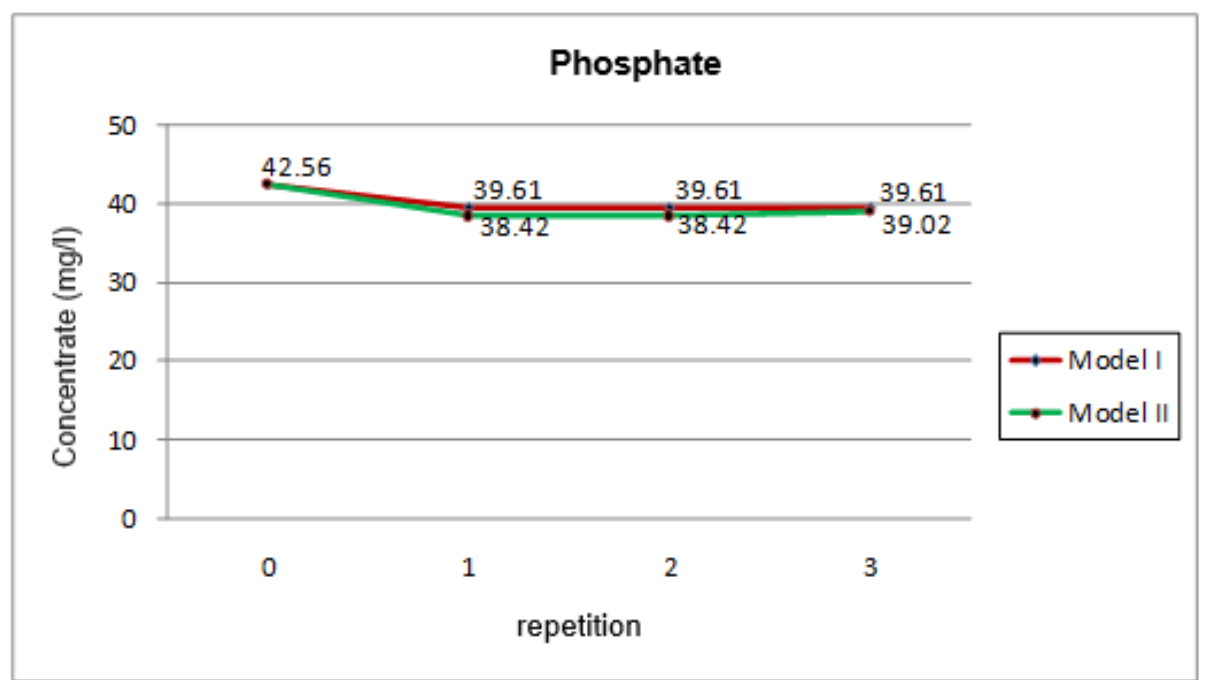

Figure 8. Comparison of laboratory test results of phosphate parameter for 5 days

Therefore, based on the difference in the average percentage of decline that occurs, it can be concluded that the modeling of constructed wetland model II which uses canna sp aquatic plant, is better in reducing Phosphate levels in detergent wastewater, when compared to the modeling of constructed wetland model I that uses sagittaria montevidensis aquatic plants, although the ratio is very small. In general, the percentage of reduction in COD parameters is greater than the percentage of reduction in Phosphate parameters. The residence time of the waste is very influential on the reduction of the tested parameters level, the longer the residence time, the greater the decrease that occurs.

The percentage of reduction in COD parameters in model I was greater than the percentage of reduction in COD parameters in model II, both for the waste residence time of 5 days and 10 days, with a difference in the percentage of reduction $67.62 \%$ and $59.93 \%$. The percentage of reduction in Phosphate parameters in model II was greater than the percentage of reduction in Phosphate parameters in model I, both for waste time of 5 days and 10 days, with a difference in the percentage of reduction $6.93 \%$ and $9.26 \%$.

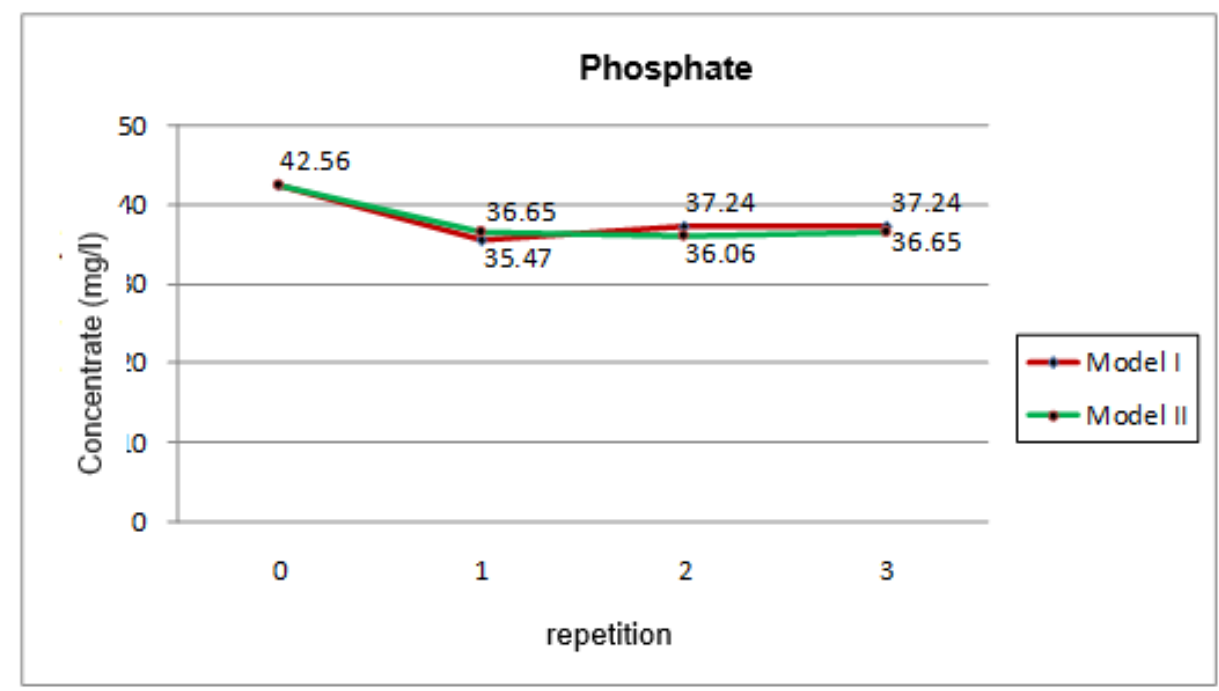

Figure 9. Comparison of laboratory test results of phosphate parameter for 10 day 


\subsection{Changes in Plant Growth}

The growth of both aquatic plants used in the installation of constructed wetland modeling can reproduce well. This can be indicated by the growth of new shoots on plants and flowers from these plants during the wastewater treatment process up to the last observation (Figure 10). Aquatic plants used can reproduce properly because the nutrient requirements in detergent wastewater treatment plants are sufficiently available such as phosphate ions dissolved in wastewater which is then tied first by the soil. The $\mathrm{pH}$ and temperature conditions in the constructed wetland modeling are relatively normal, which allows the chemical process to support photosynthesis of sagittaria montevidensis and canna sp plants to run normally.

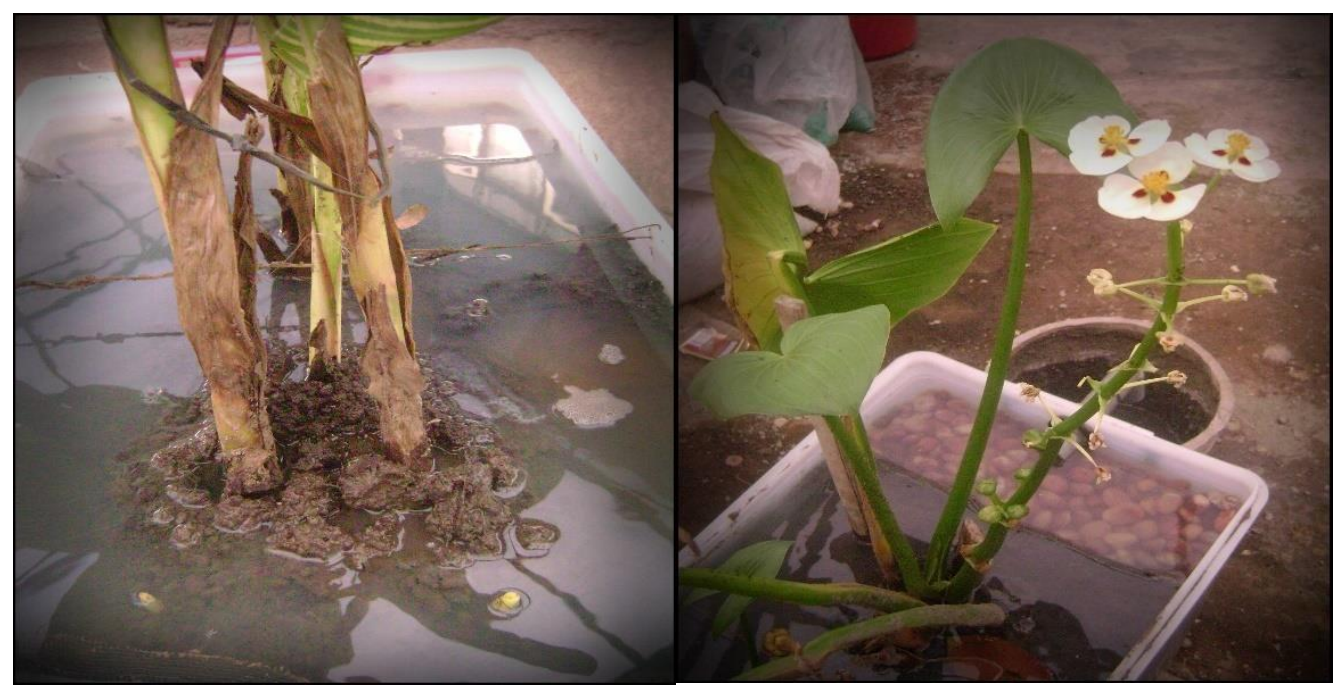

Figure 10. Shoots and flowers on aquatic plants

\section{Conclusions}

From the results of laboratory tests and calculations, both constructed wetland modeling models have been proven able to reduce the levels of COD and phosphate in detergent wastewater. The effectiveness of Constructed Wetland using Sagittaria Montevidensis plant (model I) is better in reducing COD levels, while for Canna Sp (model II) it is more effective in reducing Phosphate levels in detergent wastewater. Aquatic plants used in constructed wetland modeling can grow and reproduce well, this can be indicated by the growth of new shoots and flowers from these plants during the wastewater treatment process up to the last observation. For optimal conditions, constructed wetland modeling should be done in an open area, where plants used in constructed wetland modeling can make direct contact with sunlight, so that the photosynthesis process can be maximized, in conjunction with the absorption of nutrients contained in the modeling processing zone. In the future, further research will be carried out by considering the stability of the inlet discharge, the variation of waste residence time, the arrangement of the substrate/filter media and the use of other aquatic plants.

\section{References}

[1] Alan W. Maki, Donald B. Porcella, Richard H. Wendt, 1984. The impact of detergent phosphorus bans on receiving water quality. Water Research, Volume 18, Issue 7, 1984, Pages 893-903.

[2] Agustin N. M. Bagyo, Winarti Andayani, Christina Tri Suhani, 2014. Radiolysis of alkyl benzene sulfonat (ABS) in aqueous solution. Radiation Physics and Chemistry, Volume 69, Issue 4, March 2004, Pages 317-319.

[3] Anggraheni, E. 2004. Studi Tentang Aerasi Pada Instalasi Pengolahan Air Mikro Untuk Memenuhi Kebutuhan Air Bersih Rumah Tangga. Skripsi S1. Teknik Pengairan. Universitas 
Brawijaya. Malang.

[4] Kusuma, R.T., 2005. Studi Penurunan COD dan BOD5 Air Limbah Domestik dengan Menggunakan Subsurface Constructed Wetland dengan Menggunakan Tanaman Kana-Studi Kasus di Kampus Teknik Lingkungan ITS. Tugas Akhir, Jurusan Teknik Lingkungan ITS, Surabaya.

[5] Yuanita, C. 2003. Pengaruh variasi media tanaman terhadap penurunan kandungan organic (PV) dan TSS pada pengolahan efluen IPLT Keputih, Sukolilo Surabaya dengan menggunakan tanaman cattail (Typha latifolia) menggunakan system constructed wetlands. Tugas akhir Jurusan Teknik Lingkungan ITS. Surabaya.

[6] Riyanto Haribowo, Minami Yoshimura, Masahiko Sekine, Tsuyoshi Imai, Koichi Yamamoto, Takaya Higuchi, Ariyo Kanno., 2017. Behavior of toxicity in river basins dominated by residential areas. Contemporary Engineering Sciences 10 (7), 305-315.

[7] H Yamashita, R Haribowo, M Sekine, N Oda, A Kanno, Y Shimono, W Shitao, T Higuchi, T Imai, K Yamamoto., 2012. Toxicity test using medaka (Oryzias latipes) early fry and concentrated sample water as an index of aquatic habitat condition. Environmental Science and Pollution Research 19 (7), 2581-2594.

[8] Zhao Zhimiao, Song Xinshan, Wang Yuhui, Wang Daoyuan, Wang Suyan,He Yuan, Ding Yi, Wang Wei, Yan Denghua, Wang Junfeng., 2016. Effects of algal ponds on vertical flow constructed wetlands underdifferent sewage application techniques. Ecological Engineering 93 (2016) 120-128.

[9] Jih Ming Chyan, Chien Jung Lin, Yu Chi Lin, Yi An Chou., 2016. Improving removal performance of pollutants by artificial aerationand flow rectification in free water surface constructed wetland. International Biodeterioration \& Biodegradation, Volume 113, September 2016, Pages 146-154.

[10] Huaqing Liu, Zhen Hu, Jian Zhang, Huu Hao Ngo, Wenshan Guo, Shuang Liang, Jinlin Fan,Shaoyong Lu, Haiming Wu., 2016. Optimizations on supply and distribution of dissolved oxygenin constructed wetlands: A review. Bioresource Technology, Volume 214, August 2016, Pages 797-805.

[11] Demin Zhou, Hong Zhang, Chengliang Liu., 2016.Wetland ecohydrology and its challenges. Ecohydrology \& Hydrobiology 16 (2016) 26-32.

[12] Robert L Knight, William E Walton, George F O’Meara, William K Reisen, Roland Wass., 2003. Strategies for effective mosquito control in constructed treatment wetlands. Ecological Engineering, Volume 21, Issues 4-5, 31 December 2003, Pages 211-232.

[13] C. Ramprasad, Chris Shirley Smith, Fayyaz A. Memon, Ligy Philip ., 2017. Removal of chemical and microbial contaminants from greywater using a novel constructed wetland: GROW. Ecological Engineering, Volume 106, Part A, September 2017, Pages 55-65.

[14] Wilfred W. Scott., 1920. Standard Methods of Chemical Analysis. D. Van Nostrand Company.

[15] Cooper, P., 1999. Wetland System for Water Pollution Control. Wath scie Pergamon. Germany.

[16] R Haribowo, V Dermawan, SN Yudha., 2018. Application of Artificial Neural Network For Defining The Water Quality in The River. Civil and Environmental Science Journal 1 (01), 12-18, 2018. 